Goldschmidt 2021 Abstract

https://doi.org/10.7185/gold2021.6210

\section{Mineralogical and geochemical characterisation of the Kipawa peralkaline complex: implications for rare-earth element deposits.}

\author{
SIMON MATTE ${ }^{1}$, MARC CONSTANTIN ${ }^{1}$ AND \\ STEVENSON ROSS ${ }^{2}$ \\ ${ }^{1}$ Université Laval \\ ${ }^{2}$ UQAM \\ Presenting Author: simon.matte.2@ulaval.ca
}

The Kipawa rare-earth element (REE) deposit is located in the Parautochton zone of the Grenville Province $55 \mathrm{~km}$ south of the boundary with the Superior Province. The deposit is part of the Kipawa syenite complex of peralkaline syenites, gneisses, and amphibolites that are intercalated with calc-silicate rocks and marbles overlain by a peralkaline gneissic granite. The REE deposit is principally composed of eudialyte, mosandrite and britholite, and less abundant minerals such as xenotime, monazite or euxenite. The Kipawa Complex outcrops as a series of thin, folded sheet imbricates located between regional metasediments, suggesting a regional tectonic control. Several hypotheses for the origin of the complex have been suggested: crustal contamination of mantle-derived magmas, crustal melting, fluid alteration, metamorphism, and hydrothermal activity. Our objective is to characterize the mineralogical, geochemical, and isotopic composition of the Kipawa complex in order to improve our understanding of the formation and the post-formation processes, and the age of the complex.

The complex has been deformed and metamorphosed with evidence of melting-recrystallization textures among REE and $\mathrm{Zr}$ rich magmatic and post magmatic minerals. Major and trace element geochemistry obtained by ICP-MS suggest that syenites, granites and monzonite of the complex have within-plate A2 type anorogenic signatures, and our analyses indicate a strong crustal signature based on TIMS whole rock $\mathrm{Nd}$ isotopes. We have analyzed zircon grains by SEM, EPMA, ICP-MS and MC-ICPMS coupled with laser ablation (Lu-Hf). Initial isotopic results also support a strong crustal signature. Taken together, these results suggest that alkaline magmas of the Kipawa complex/deposit could have formed by partial melting of the mantle followed by strong crustal contamination or by melting of metasomatized continental crust. These processes and origins strongly differ compare to most alkaline complexes in the world. Additional TIMS and LA-MC-ICP-MS analyses are planned to investigate whether all lithologies share the same strong crustal signature.

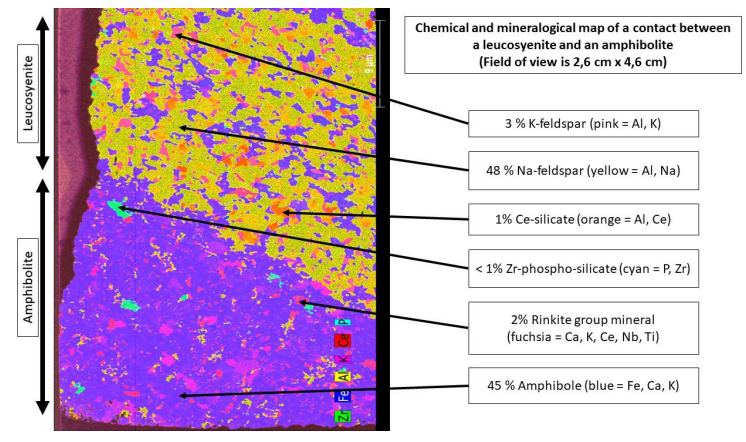

